\title{
Public Libraries and Adult Fiction: Another Look at a Core List of "Classics"
}

\section{Judith J. Senkevitch and James H. Sweetland}

\begin{abstract}
In this study, we examined the extent of change over a one-year period in the adult fiction titles most widely held by over 4,000 OCLC Online Computer Library Center, Inc. member public libraries in order to clarify the degree of stability of a consensus list of most-held adult fiction. The study is part of a continuing research effort to contribute to the understanding of the nature of adult fiction collections in public libraries and to develop useful models to assist librarians in evaluating their adult fiction collections. Findings indicate that the most widely held adult fiction titles are recent, popular works that form a stable core from one year to the next; results also suggest that such a listing of widely held titles might be suitable as an evaluation tool in smaller public libraries. The implications of these findings are discussed and recommendations are made for further research.
\end{abstract}

\begin{abstract}
A
part of an ongoing effort to understand the nature of adult fiction collections in public libraries and to develop methodologies and tools to assist practitioners in evaluating fiction collections, we have conducted a series of research projects to examine various aspects of evaluating public library adult fiction. In an initial study undertaken in 1992 of evaluation practices and concerns in small and medium-sized Wisconsin public libraries, we found that a large majority of librarians had evaluated their adult fiction collections within the previous five years (Senkevitch and Sweetland 1994). However, in that study and others, researchers also found that many librarians in smaller libraries do not distinguish between evaluation and weeding, and that they are
\end{abstract}

reluctant to weed lest they discard a work that might return to favor (Truett 1990). This is particularly a concern in smaller libraries with very limited resources. There is both a need for and lack of understanding of ways to identify adult fiction titles that will remain popular or endure.

Seeking to address that question, we next undertook a study, funded by the OCLC Online Computer Library Center to determine whether a core list of adult fiction titles widely held by public libraries could be identified for use in evaluating adult fiction collections (Sweetland and Senkevitch 1995; Senkevitch and Sweetland 1996). In that study, we also examined whether commonly used collection development lists of recommended titles or lists of bestsellers would be useful

Judith J. Senkevitch (senkevit@csd.uwm.edu) and JAmes H. SweEtland (sweetlnd@ csd.uwm.edu) are associate professors at the School of Library and Information Science, University of Wisconsin-Milwaukee. Manuscript received December 5, 1997; accepted for publication February 10, 1998. 
in predicting widely held works. Using the OCLC Online Union Catalog (OLUC) of over 30 million records, we identified the approximately 400 adult fiction titles most widely held by public library participants in OCLC (Senkevitch and Sweetland 1996). While our findings suggested that this core list might be useful as an evaluation tool, they also raised questions about the stability of the list. Would the same titles remain on the list of widely held works from one year to the next, or would there be substantial change in the makeup of the list? We had an underlying assumption that a fiction work widely held by public libraries would in some sense be "classic," and prevalence in public library collections rather than, for example, inclusion in a "literary canon," formed the basis for the operating definition of "classic" in the study. The issue of longevity on the list-the stability of a title-raised an important question in this regard.

As part of the 1993-94 project, OCLC staff produced two lists of widely held public library adult fiction titles: one list in December 1993 that contained a total count of the holding codes for all manifes tations, and a second list in August 1994 that contained a count of the individual libraries holding a given title. While some variation in the titles included on the two lists might reasonably have been expected with the modification in the parameters of the database run, examination of the two lists showed that more than $20 \%$ of the titles changed from the first to the second list within this brief period. In addition, the numbers of holdings had increased substantially for many remaining titles in the eight months between the generation of the two lists, a phenomenon also not necessarily explained by the modification in parameters. Almost by definition, a list of "classics" would be expected to change rather slowly, if at all, over time. Findings from the 1993-94 work, however, raised questions about the degree of volatility of the list of adult fiction most likely to be held by U.S. public libraries that are participants in OCLC.

Therefore, in order to explore further the potential usefulness of such a listing as an evaluation tool and to examine sys- tematically the degree of volatility of titles on the list, we undertook a second study, funded by OCLC, in 1995-96. In this second study, we generated a new list of 400 adult fiction titles most widely held by OCLC member public libraries in 1995 and compared that list with the 1994 list to examine the relative stability of the listing. The findings of this latter study are reported here. While a brief background on key issues relating to public library collection evaluation and the role of popular materials is also provided, readers are referred to previous works (Sweetland and Senkevitch 1995; Senkevitch and Sweetland 1996) for a fuller discussion of these topics.

\section{RESEARCH QUESTIONS AND HYPOTHESES}

The principal research questions addressed by this study are:

Question 1. Does the emphasis in public libraries on providing current popular reading appear to lead to relatively rapid changes in the titles held by those libraries?

Question 2. If not, could a core list of such titles be developed to assist librarians in collection evaluation?

In addition, the study provided insights into what constitutes a "fiction classic." Hypotheses tested included the following:

Hypothesis 1. The listing of adult fiction titles most widely held by OCLC member public libraries will change within one year, with many titles dropping from the list and new titles taking their place.

Hypothesis 2. Titles with more recent publication dates will show a larger increase in number of holding libraries than those titles with older publication dates.

Hypothesis 3 . Titles with older publication dates will be more likely to drop from the list than those with recent dates.

Hypothesis 4. Those titles added to the list from one year to the next will be those with recent publication dates. 
Hypothesis 5. Those titles with more recent publication dates will show a greater increase in number of different OCLC records (as a result of new editions and different formats) than those titles with older publication dates.

\section{BaCkground}

Almost since the beginning of the public library as an institution, a primary use of these collections has been for reading fiction. While the exact percentage of total circulation accounted for by adult fiction has varied over time (Goldhor 1985), fiction remains the most common adult material taken out of the library (Johnson 1989; Vavrek 1990; Westin and Finger 1991). Analyses of the roles selected by public libraries consistently indicate popular materials center as the most commonly selected primary role (McClure et al. 1987; Baker 1993; Shearer 1993; Senkevitch and Sweetland 1994).

Although it is clear that fiction for adults is an important part of public library collections, there has been surprisingly little research on such collections (Sweetland 1991; Senkevitch and Sweetland 1994), Researchers in a number of studies have pointed out the value of display and promotion in increasing circulation-notably Baker (1986, 1988), Long (1986), and Parrish (1986). While useful, unfortunately, these and other authors suggest that circulation, being easily manipulated, is not a good measure of value. The authors of two key works on library collection weeding unfortunately give somewhat conflicting advice. Slote (1971, 1989) recommends relying solely on circulation, but he argues that in each library the relevant time-on-shelf must be calculated individually, because such time might vary from two months to nearly ten years. In the revised CREW (Continuous Review, Evaluation, and Weeding) manual on weeding, Boon (1995) suggests considering a time-on-shelf since last circulation of two years as a viable figure for weeding decisions for fiction, in contrast to Slote's varying figure. Boon also suggests considering a title's presence on lists of recom- mended fiction and award-winners in the weeding process.

A relatively recent approach to collection evaluation, initially developed by the Research Libraries Group, is the conspectus approach, in which a relatively close classification of the entire collection is used as the basis for evaluation. Given its apparent success for larger academic libraries, the approach has been adapted not only for nonfiction collections but also for fiction, even though the latter is not traditionally classified by libraries (Collection Building 1994). The basic elements suggested for fiction evaluation are age of material, use (based on circulation data), and relative size of the given genre or category compared with the collection as a whole. Quality judgments for fiction are made by looking at size and growth rate, number of authors and titles owned, and desired intensity of collection for each genre. A further test of quality refers to current lists of awards and honors, presence on lists of "classics," and recent lists of ALA Notable Book awards (Baker 1994).

It is clear that both librarians and the public believe that fiction for adults is an important part of public library collections. However, despite this, there has been almost no research on how to improve this important aspect of public library service. Similarly, while librarians agree on the need for evaluation and weeding of fiction collections, there is little information on how to do it. One aspect of the problem identified in earlier research (Senkevitch and Sweetland 1994) is the lack of reliable ways to identify fiction "classics" when selecting and weeding. This study addresses that issue.

As of August 1994, there were over 18,300 participating libraries in the OCLC system; the OLUC contained nearly $31 \mathrm{mil}-$ lion records with a combined total of approximately 527 million holding codes (OCLC Statistics 1994). In August of 1994, the date of the first list of titles generated from the database, the system included approximately 4,000 public libraries; a year later this number had grown to about 4,700 public libraries (McClain 1995). 
TABLE 1

Thirty Most-Held Titles on OClC by Number of Holdings, 1995

\begin{tabular}{lcccc}
\hline \hline & & $\begin{array}{c}\text { No. of Unique } \\
\text { Library } \\
\text { Holdings in } \\
\text { Author/Title }\end{array}$ & $\begin{array}{c}\text { Change in } \\
\text { Rank by } \\
\text { Holdings } \\
1994-95\end{array}$ & $\begin{array}{c}\text { Change in } \\
\text { Pumber of } \\
\text { Holdings } \\
1994-95\end{array}$ \\
\hline Jakes, John. North and South & 1982 & 1,090 & .0 & 39 \\
Keillor, Garrison. Lake Wobegon days & 1985 & 1,078 & .0 & 45 \\
LAmour, Louis, Last of the breed & 1986 & 1,069 & 1.0 & 43 \\
Whitney, Phyllis. Dream of orchids & 1985 & 1,068 & -1.0 & 41 \\
LAmour, Louis. The walking drum & 1984 & 1,062 & .5 & 42 \\
King, Stephen. The stand & 1978 & 1,057 & 2.0 & 50 \\
Holt, Victoria. The time of the hunter's moon & 1983 & 1,056 & -1.5 & 36 \\
Whitney, Phyllis. Flaming tree & 1985 & 1,055 & -1.0 & 43 \\
Holt, Victoria. Secret for a nightingale & 1986 & 1,047 & 2.0 & 46 \\
Walker, Alice. The color purple & 1982 & 1,047 & .0 & 43 \\
Holt, Victoria. The road to Paradise Island & 1985 & 1,043 & -1.5 & 39 \\
Auel, Jean M. The plains of passage & 1990 & 1,041 & 4.5 & 44 \\
Plain, Belva. Crescent City & 1984 & 1,041 & 5.5 & 45 \\
Marshall, Catherine. Julie & 1984 & 1,040 & -.5 & 40 \\
Le Carre, John. A perfect spy & 1986 & 1,039 & .5 & 41 \\
Ludlum, Robert. The Aquitaine progression & 1984 & 1,039 & -.5 & 40 \\
Dailey, Janet. Silver wings, Santiago blue & 1984 & 1,038 & -6.0 & 37 \\
Santmyer, Helen H. “-and ladies of the club” & 1982 & 1,038 & -4.0 & 38 \\
Michener, James A. Alaska & 1988 & 1,037 & 1.5 & 43 \\
Whitney, Phyllis, Emerald & 1983 & 1,035 & .5 & 41 \\
Howatch, Susan. The wheel of fortune & 1984 & 1,034 & -.5 & 40 \\
Holt, Victoria. The Landower legacy & 1984 & 1,032 & -2.0 & 38 \\
L'Amour, Louis. The lonesome gods & 1983 & 1,032 & 1.5 & 40 \\
Archer, Jeffrey. The prodigal daughter & 1982 & 1,031 & 7.0 & 47 \\
Freeman, Cynthia. Always and forever & 1990 & 1,028 & 2.0 & 42 \\
Steel, Danielle. Crossings & 1982 & 1,028 & .5 & 40 \\
Ludlum, Robert. The Bourne supremacy' & 1986 & 1,027 & -2.0 & 38 \\
Clancy, Tom. Clear and present danger & 1989 & 1,026 & 9.0 & 46 \\
McMurtry, Larry. Lonesome dove & 1985 & 1,025 & 3.0 & 42 \\
Follett, Ken. Lie down with lions & 1985 & 1,023 & 2.5 & 41 \\
\hline
\end{tabular}

This represents approximately $43 \%$ of all United States public libraries (American Library Directory 1997).

\section{METHODS}

Using the OLUC, we worked with OCLC research staff to generate a list of the approximately 400 adult fiction titles most widely held by OCLC member public libraries in 1995. Following the parameters used in the 1993-94 analysis, we isolated the records of public libraries from those of other libraries; eliminated non-English materials, nonbook materials, serials, and government publications by use of MARC document type fields; and identified fiction by use of the fixed field code. Multiple records for various editions of the same title were then merged under a single title, and duplicate library holding codes were eliminated. Experience in the previous project showed that because of varying editions and cataloging practices, juvenile material cannot effectively be removed during initial list creation. Therefore, juvenile titles were identified by checking for "juvenile" coding (for a standard unabridged edition) in Books in Print Plus on CD-ROM. All titles were 
TABLE 2

Most-Held Adult Fiction on OCLC, Dropped in 1995

\begin{tabular}{lccc}
\hline \hline Author/Title & Date & Holdings in 1994 & Rank in 1994 \\
\hline Byars, Betsy Crom. The not-just-anybody family & 1986 & 866 & 395.5 \\
Collins, Jackie, Hollywood wives & 1983 & 865 & 403.0 \\
Condon, Richard. Prizzi's family & 1986 & 872 & 368.0 \\
Condon, Richard. Prizzi's glory & 1988 & 875 & 352.0 \\
DeLillo, Don. Libra & 1988 & 871 & 3750 \\
Erdman, Paul Emil. The palace & 1985 & 872 & 368.0 \\
Eidrich, Louise. The beet queen & 1986 & 865 & 403.0 \\
Flagg, Fannie. Coming attractions & 1981 & 897 & 229.5 \\
Gardner, John E. Icebreaker & 1983 & 866 & 395.5 \\
Miller, Sue. Family pictures & 1990 & 867 & 389.5 \\
Stewart, Fred M. Ellis Island & 1983 & 871 & 375.0 \\
Updike, John. S & 1988 & 867 & 389.5 \\
Vonnegut, Kurt. Bluebeard & 1987 & 865 & 403.0 \\
\hline
\end{tabular}

also checked in Wilson's Fiction Catalog. Where a title was listed in Books in Print Plus as juvenile and also included in Fiction Catalog, it was designated, for purposes of this study, as "young adult" rather than children's. The 90 titles flagged as juvenile (both the 41 designated "young adult" and the 49 children's works) were eliminated from further consideration at this point.

As with the earlier study, clarifying "title" remained a challenge. Variant records exist for what appear to be the same title. For example, A Visit from St. Nicholas also appears as "Twas the Night Before Christmas and The Night Before Christmas. In most cases, OCLC was able to resolve this in the merging process. However, in 8 cases, alternate listings were generated for what appear to be the same work. Because all of these instances involved works identified in the analysis process as "juvenile," they were set aside for future study because the focus of this project is adult fiction. However, when the juvenile works are ultimately analyzed as a separate listing of highly held works, additional effort will be needed to clarify why certain older titles eluded the merging process.

The list of adult titles produced in August 1995 was compared with the earlier one to examine the degree of volatility of the core list of adult fiction as it applies to OCLC member libraries.
Appropriate statistical tests were made using SPSS (Statistical Package for the Social Sciences) to determine the validity of hypotheses.

\section{ANALYSIS OF Findings}

The final 1995 list of adult fiction most widely held by OCLC public libraries resulted in 409 titles, with 13 titles dropping from the earlier 1994 list and 16 additional titles appearing. The vast majority of titles are relatively recent, with publication dates since 1980. Table I lists the 199530 most-held adult fiction titles, in order by number of OCLC public libraries holding the work. Further details of the results are discussed below.

Hypothesis 1. The listing of adult fiction titles most widely held by OCLC member public libraries will change within one year, with many titles dropping from the list and new titles taking their place. This hypothesis must be rejected. Only 13 titles from the 1994 list failed to appear on the 1995 list, while only 16 new titles appeared on the 1995 list. This represents a change of approximately $3.2 \%$ over one year. At this rate of change it would, in theory, take at least 30 years for the entire list to be replaced.

Hypothesis 2. Titles with more recent publication dates will show a larger increase in number of holding libraries than those titles with older publication dates. 
TABLE 3

Most-Held Adult Fiction on OCLC, AdDEd in 1995

\begin{tabular}{lccc}
\hline \hline Author/Title & Date & Holdings & Rank \\
\hline Bradford, Barbara. The women in his life & 1990 & 908 & 374.0 \\
Crichton, Michael. Congo & 1980 & 923 & 301.5 \\
Fitzgerald, F. Scott. The great Gatsby & 1925 & 910 & 361.5 \\
Grafton, Sue. "C" is for corpse & 1986 & 907 & 380.5 \\
Greeley, Andrew M. Angel fire & 1988 & 903 & 398.0 \\
Higgins, Jack. Touch the devil & 1982 & 907 & 380.5 \\
Irving, John. The cider house rules & 1985 & 908 & 374.0 \\
Keneally, Thomas. Schindler's list & 1982 & 924 & 295.0 \\
Macdonald, John D. The lonely silver rain & 1985 & 901 & 407.0 \\
Michaels, Barbara. Into the darkness & 1990 & 908 & 374.0 \\
Plain, Belva. Harvest & 1990 & 912 & 356.5 \\
Sanders, Lawrence. The Timothy files & 1987 & 901 & 407.0 \\
Sanders, Lawrence. The seventh commandment & 1991 & 905 & 389.5 \\
Sheldon, Sidney. The stars shine down & 1992 & 904 & 392.5 \\
Steel, Danielle. Message from Nam & 1990 & 906 & 385.0 \\
Truman, Margaret. Murder in the White House & 1980 & 903 & 398.0 \\
\hline
\end{tabular}

Of the 393 titles that remained on the list from 1994 to 1995, those with more recent publication dates did show a slightly larger increase in number of holding libraries than those titles with older publication dates. The mean number of libraries holding a given title increased (by 39) from 915 in 1994 to 954 in 1995; the median increased (by 41) from 904 to 945 . Depending upon how "older" and "newer" are defined, analysis using t-tests and correlations suggests that there is a very slight tendency for newer titles to show a greater increase in holdings (approximately 3 more per title) than older titles. Because very few titles on either list were published before 1968, these can be eliminated as outliers. When the oldest titles are removed, there is a very weak Pearson correlation of .1388 ( $\mathrm{p}<.006)$ between increase in holdings and date of publication, which suggests that libraries may be emphasizing newer titles.

In dealing with holdings changes, it is important to remember that OCLC is a very dynamic database; member libraries continue to add new holdings, and at the same time new libraries become members. For these new libraries, records are added for older holdings as well as new accessions. As noted above, the number of public librar- ies with holding codes on OCLC went from approximately 4,000 in August of 1994 to 4,700 in August of 1995. Due primarily to the continued addition of new public libraries to OCLC, the total number of unique holdings attached to a given title has increased over time. One dramatic way of illustrating this fact is to note the cutoff point for the 400 most-held titles. In 1994, this was 865 (i.e., the last title on the list was held by 865 libraries), yet in 1995, the same number of titles was reached at 901 .

Hypothesis 3. Titles with older publication dates will be more likely to drop from the list than those with recent dates. In fact, titles with older publication dates are no more likely to drop from the list of widely held titles than those with recent dates. Of the 13 titles dropped from the 1994 list (see table 2), the oldest was published in 1981 and the newest in 1990, for mean and median dates of ca. 1986. The 16 titles added (see table 3 ) had a mean publication date of ca. 1983. In comparison, the 393 titles that remained on the list had publication dates ranging from 1886 to 1991 , with a mean publication date of ca. 1985 and a median date of 1986. T-tests showed no significant difference in dates between those titles that dropped and those that did not drop from 
the list, nor any significant difference between those dropped and those added. However, caution must be exercised because of the small numbers of titles involved in this analysis.

Hypothesis 4. Those titles added to the list from one year to the next will be those with recent publication dates. The 16 titles added (see table 3) to the list in 1995 tended to be those with more re cent publication dates; however, the overall difference in publication dates between those titles added and those dropped was not statistically significant. Only one of the 16 titles added to the list was published before 1980, F. Scott Fitzgerald's The Great Gatsby (1925). Including that title, the mean date of titles added was ca. 1983, the median ca. 1987. On the other hand, only one of the new titles had a 1992 publication date, and one a 1991 date; there were no titles added with publication dates more recent than 1992

Hypothesis 5. Those titles with more recent publication dates will show a greater increase in the number of different OCLC records (as a result of new editions and different formats) than those titles with older publication dates. This proved not to be the case. The 393 titles on both lists showed a mean number of OCLC manifestations in 1994 of 8.7, with a median of 8 ; in 1995 the mean number of manifestations per title was 8.99 , with a median of 8 . However, $77.4 \%$ (304) of the continuing titles showed no change in the number of manifestations. Of those titles showing a change in the number of manifestations from 1994 to 1995, 5 actually showed a drop (possibly due to consolidation of records), 64 titles showed an increase of only 1 manifestation, 13 an increase of 2,2 an increase of 3 , and 3 titles an increase of 4 manifestations. Among those titles with increased manifestations are two of the oldest titles (1886 and 1936), as well as one of the newest (1991). For the 83 titles that showed an increase in manifestations, the mean publication date was ca, 1984 (median 1986), showing no significant difference from the list as a whole. Further, the number of OCLC records for a title did not show any statistically significant relationship with the numbers of libraries holding the title.

Although there is no correlation between publication date and changes in holdings or rank for the 393 titles in both lists, there is a very high correlation between the publication date of a title and the total number of different records for it. In the 1994 list, this is -.8338 and in $1995-.8297$, both significant at $<.0001$. In other words, the older the record the greater the number of manifestations. This is not surprising, because older titles are more likely than newer ones to have been issued in various editions over the years.

\section{Changes in Rank over One Year}

As noted above, there was relatively little change in the whole list of titles over a year. However, the ranking of some individual titles shifted drastically from the 1994 to the 1995 list. There are a total of 422 titles in the combination of the two adult lists: of these, 13 dropped from the list over a year, and 16 were added. Obviously, it is not possible to discuss rank change among these titles, but such comparison is valid for the 393 found on the 1994 list that were still on the 1995 listing. Titles dropped from the 1994 list tended to be those toward the bottom of the rankings.

The "average" title actually dropped very slightly in rank (by .24); the median rank change was .5. The greatest drop was 96 positions, while the greatest increase was 107 positions; 5 titles did not change rank, and 12 changed only a half position. These titles with little or no change in rank appear to have little in common, other than that fact and their relatively high rank.

\section{Is There a Consensus Core of ADULT FICTION?}

Our findings suggest that the list of mostheld fiction titles is relatively stable and that the OLUC could, in fact, be used as a "consensus list" of adult fiction suitable for public libraries. However, while the 
1995 OLUC contained, in theory, the holdings of approximately 4,700 public libraries (as defined by holding codes in the OLUC), it is quite notable that the most-held work was owned by only 1,090 libraries, and that the 5 titles ranking 407th were held by only 901 libraries. When a list of the top 400 contains titles owned by only $19.2 \%$ of public libraries in the system, one could question the meaningfulness of the consensus.

Studies of overlap among collections in public libraries are very rare to date, even with the increased emphasis on cooperative collection development (Collection Building 1994). The only largescale public library study is that conducted by Shaw (1985), in which 20 academic and 20 public library collections were compared. The overall figures show very little duplication of collections: $63 \%$ were owned by 5 or fewer libraries, while $20 \%$ of the titles were owned by only 1 library. When the titles selected from public libraries were checked only in public libraries, $32 \%$ were found to be held in only 1 library.

The authors of the few studies dealing expressly with fiction are primarily interested in juvenile materials. Rozek (1990), for example, selected titles from the H.W. Wilson Junior High School Library Catalog and then compared holdings in a public library with 4 junior high school libraries in the same community. All 25 selected titles were held by the public library, while the 4 school libraries held between 18 and 22 of the titles. Comparing holdings of selected fiction and nonfiction titles in 4 public libraries with 2 school libraries from each community, Doll (1984) consistently found the public libraries were more likely to hold the selected titles than the schools.

The literature on academic libraries might provide some guidance, although most of these authors have only considered nonfiction material. McGrath and Simon (1972) found little overlap among the holdings of 16 Louisiana academic libraries, with roughly $83 \%$ of the titles sampled held by only 1 library. Moore et al. (1982) reported on a study done in 1977-79 of 11 University of Wisconsin libraries, using the
OCLC database as a catalog surrogate, and found that $82 \%$ of titles were held by only 1 library examined.

Authors of more recent studies using OCLC have generally found somewhat higher duplication among academic library collections. For example, Potter (1986) found $69 \%$ of titles in 22 Illinois academic libraries were uniquely held. Hardesty and Mak (1994) found $49 \%$ of titles were held by only 1 of 64 smaller college libraries. Hardesty and Mak further found only $29 \%$ of titles with publication dates from 1980 to 1990 were held uniquely among the 427 smaller academic libraries examined. They also are among the very few to provide information on material in the Library of Congress P classifications (especially $\mathrm{PN}$ through $\mathrm{PZ}$ ), the closest approximation to the fiction focus in our study. Depending on the specific call number, there were between $23 \%$ and $51 \%$ of these recently published titles that were uniquely held among the 427 libraries.

Descriptions of and research about the use of collective lists of library holdings suggest that the analysis of peer group collections to create a baseline for evaluating one's own collection might have value. While there is little literature regarding fiction or public library collections, analyses of academic library collections suggest that there might be a very small core of widely owned titles. Thus, titles held by approximately one-fifth of all OCLC member public libraries might well represent sufficient consensus to serve as a core list of public library adult fiction. While not all public libraries currently catalog all their fiction holdings on OCLC, the data from this study are based on a sample of nearly $4.3 \%$ of all U.S. public libraries. Anecdotal evidence also suggests that where fiction holdings are not recorded on OCLC, the fiction least likely to be cataloged consists of paperbacks, rental collections, and ephemera. Thus, if the holdings data are not inclusive of all fiction owned by libraries, the data are most likely skewed against library holdings of current ephemeral fiction, which is retained only during a year or two of popu- 
larity, and in favor of the fiction more likely to be retained over time.

\section{Conclusions AND \\ RECOMMENDATIONS FOR FURTHER RESEARCH}

In our previous research, we tested the predictive validity of commonly used lists, including both quality lists (such as ALA Notable Books) and quantity lists (such as the Publishers Weekly bestseller lists) as predictors of the titles held by the greatest number of public libraries (Sweetland and Senkevitch 1995; Senkevitch and Sweetland 1996). Those results show that, with the exception of the Wilson Fiction Catalog, the lists currently most commonly used do not represent a consensus core collection for public libraries in the United States. As such, their value as quality estimators for the purpose of collection evaluation is, at best, weak.

However, the findings presented here suggest that the OCLC list of most-held adult titles is relatively stable over time; that newly published titles do not automatically get purchased by public libraries in large quantities; and that such a listing could, in fact, be used as a consensus list of adult fiction suitable for public library collection evaluation.

\section{DEFINING A "ClaSsic"}

The issue of what constitutes a fiction classic requires further examination. Most of the 41 widely held works now designated "young adult" were well-known older titles, such as Jack London's Call of the Wild and Charlotte Brontë's Jane Eyre, originally published for adults but now frequently on school reading lists. The removal of those titles classified as "juvenile" from the list of mostheld adult fiction effectively eliminated most older works frequently regarded as classics. We are presently examining these titles in hopes of explaining the phenomenon that appears to define "classics" as, in effect, older books initially written for adults that have become suitable for youthful reading.

\section{IMPACT OF MEDIA ON LIBRARY} HOLDINGS

Examination of the two lists suggests another factor-in addition to perceived quality, past circulation in a given library, and the like - that might influence library purchase decisions. This is the impact of movies or television on titles appearing on the list of most-held works, what might be termed the "media event," A number of the titles that appeared on the list, or that showed considerable increase in ranking, can be connected with the creation of a motion picture or television miniseries based on the work. During the course of this study, motion pictures or television miniseries were released based on The Hunchback of Notre Dame, Dracula, The Great Gatsby, and several of Jane Austen's novels, for example. We plan to examine this phenomenon in detail in the near future. In the meantime, it will be very interesting to see whether such titles rise into the top 400 by next year.

\section{Nature of The Most-Held List}

While only two years' study does not provide sufficient data to make solid conclusions, some speculation about the list might be in order. For example, it is intriguing that a new work seems to take several years to become widely held: the newest title added to the list in 1995 was a 1992 publication; 1 title was from 1991, and 4 from 1990. The oldest title added, from 1925 , might well be an anomaly, because the other 15 all date from the $1980 \mathrm{~s}$. The 1925 title added, Fitzgerald's Great Gatsby, might also be an example of the impact of a media event, as discussed above.

If this pattern is typical over time, it suggests several points. For one thing, at least the adult fiction that becomes widely held does not apparently go out of print rapidly. Similarly, the fact that new titles do not immediately appear on the list might indicate the care with which public libraries select their adult fiction. Regardless of a book's bestseller status or notoriety, it would seem libraries do not immediately "jump on the bandwagon," but rather confirm serious 
interest in their community before cataloging a new title.

The same data can also be used in another way to suggest that public libraries, at least with adult fiction, are sensitive to their local clientele, in that there is relatively little overlap among collections.

\section{Other AREAS FOR FUtURE STUdY}

In the present study, we address library ownership - not patron use-of adult fiction. However, we now have evidence that the list of "classics" is relatively stable. This suggests that the list could be used to analyze public library circulation patterns of these widely held titles. Results of such research would help confirm or deny the validity of this approach. In particular, knowing whether or not the titles generally popular among public libraries are also popular with any given library's users would add to knowledge relevant to the demand-versus-quality debate and provide additional insights into the nature and use of adult fiction collections. Further, an analysis of data by region and size of library might provide additional insights into library collecting of fiction.

Another area of future study concerns the children's and young adult works on the lists. It should be remembered that the original lists generated by OCLC each included 498 titles, with approximately 90 titles in each list being currently marketed to juveniles, even though many are also listed in Wilson's Fiction Catalog. We will work on this list to determine possible features of these titles over the next year.

In addition, given the surprising stability of the adult fiction list over one year and the lack of sufficiently large numbers of new titles for rigorous analysis, it would be very useful to retain the programming used to generate these lists of highlyheld adult fiction in order to extend the analysis over a longer period of time, such as five or ten years. This would provide additional insights into the nature of public library adult fiction collections and into the longer-term value of an OCLC list of most held works as a public library collection evaluation tool.

\section{WORKS CITED}

American library directory 1997-1998. 1997. 50 th ed. New Providence, N.J.: Bowker.

Baker, Sharon. 1986. The display phenomenon: An exploration into factors causing the increased circulation of displayed books. Library quarterly 56: 237-57.

- 1988. Will fiction classification schemes increase use? $R Q$ 27: 366-76.

— 1993. The responsive public library collection: How to develop and market it. Englewood, Colo.: Libraries Unlimited.

- 1994. Quality and demand: The basis for fiction collection assessment. Collection building 12 (3/4): 65-68.

Boon, Belinda 1995. The CREW method: Expanded guidelines for collection evaluation and weeding for small and mediumsized public libraries. Rev. and updated. Austin, Texas: Texas State Library.

Cooperative collection management: The conspectus approach [special issue]. 1994. Collection building 12 (3/4).

Doll, Carol A. 1984 A study of overlap and duplication among children's collections in selected public and elementary school libraries. Library quarterly 54: 277-89.

Goldhor, Herbert 1985. A summary and review of the indexes of American public library statistics: 1939-1983. Urbana, Ill.: Library Research Center, University of Illinois, ERIC Document ED 264879.

Hardesty, Larry, and Collette Mak. 1994. Searching for the Holy Grail: A core collection for undergraduate libraries. Journal of academic librarianship 19: 362-71.

Johnson, Debra W. 1989. Public library circulation holds steady in 1988. American libraries 20: 705 .

Long, Sarah P. 1986. The effect of face-front display on the circulation of books in a public library. Master's thesis, University of North Carolina at Greensboro. ERIC Document ED 278415.

McClain, Pat 1995. E-mail message 5 October. McClure, Charles, and others. 1987. Planning and role setting for public libraries. Chicago: ALA.

McGrath, William, and Donald J. Simon 1972. LNR: Register of books in Louisiana libraries; Basic documents I. Baton Rouge, La.: Louisiana Library Association. ERIC Document ED 070470.

Moore, Barbara, and others. 1982. Title overIap: A study of duplication in the Univer- 


\section{2/LRTS • 42(2) • Senkevitch and Sweetland}

sity of Wisconsin system libraries. College \& research libraries 42: 14-22.

OCLC statistics. 1994. OCLC newsletter 210 (July/August): 11.

Parrish, Nancy B. 1986. The effect of a booklist on the circulation of fiction books which have not been borrowed from a public library in four years or longer. Master's thesis, University of North Carolina at Greensboro. ERIC document ED 282564.

Potter, William G. 1986. Collection overlap in the LCS network in Illinois. Library quarterly 56: 119-41.

Rozek, Jane. 1990. A small-scale investigation of the overlap of school and public library collection development. Illinois libraries 72: 161-63.

Segal, Joseph P. 1980. Evaluating and weeding collections in small and medium-sized public libraries: The CREW method. Chicago: ALA.

Senkevitch, Judith, and James H. Sweetland. 1994. Evaluating adult fiction in the smaller public library. $R Q$ 34: 78-89.

—. 1996. Evaluating public library adult fiction: Can we define a core collection? RQ 36: 103-17.

Shaw, Debora. 1985. Overlap of monographs in public and academic libraries in Indiana. Library \& information science research 7: 275-98.
Shearer, Kenneth. 1993. Confusing what is most wanted with what is most used: A crisis in public library priorities today. $P u b$ lic libraries 32: 193-97.

Slote, Stanley J. 1989. Weeding library collections, 3d ed. Englewood, Colo.: Libraries Unlimited.

— 1971. Identifying useful core collections: A study of weeding fiction in public libraries. Library quarterly 41: 25-34.

Sweetland, James H. 1991. Managing adult fiction collections in public libraries. In Managing fiction in libraries, ed. Margaret Kinnell, 81-100. London: Library Association.

Sweetland, James H., and Judith J. Senkevitch. 1995. Evaluating public library fiction collections: Is there a core list of classics? In Annual review of OCLC research 1994. Dublin, Ohio: OCLC, 59-61.

Truett, Carol. 1990. Weeding and evaluating the reference collection: A study of policies and practices in academic and public libraries. Reference librarian 29 : 53-67.

Vavrek, Bernard. 1990. Assessing the information needs of rural Americans. Clarion, $\mathrm{Pa}$.: College of Library Science, Clarion University of Pennsylvania.

Westin, Alan F., and Anne L. Finger. 1991. Using the public library in the computer age. Chicago: ALA. 